\title{
Estimation of Environmental Conservation Effect for the Existing Urban and Suburban Forests in Japan ${ }^{1)}$
}

\author{
Suyama, Masanori*
}

\begin{abstract}
In Kansai district and the metropolitan area of Japan, there are many urban and suburban forests. These forests serve frequently as disaster prevention forests. Recently in Japan, improvement of techniques for the creation and maintenance of disaster prevention forests and urban and suburban forests has been urgent. Accordingly, existing protection forests of urban and suburban areas were firstly described. In order to find out mechanism of biotechnical slope stability maintained by tree root systems, the variety of tensile strength of tree roots between several species was discussed by comparing hillside revegetation works in urban and suburban forests. On the other hand, shear strength decreases due to distance from a solitary tree and distribution of shear strength changes at the middle of sample trees were also discussed for the urban forests in Kyoto.
\end{abstract}

要旨

陶山正憲 : わが国における都市近郊林の環境保全機能の評価

都市林や都市近郊林は，わが国では関西地方ならびに首都圈に比較的多く分布している が，これらの森林は，しばしば保安林の役目も果たしている。近年，わが国では保安林と 都市近郊林の造成・整備・管理技術の向上が強く要請されている。このような現状に鑑み, まず第一に都市及び都市近郊地区に分布する環境保全林が，議論の対象に取り上げられた。 そこで, 樹木根系による生物工学的な斜面安定機構を解明するため, まず樹種による樹木 根系の引張強度の変化が比較検討された。一方, 孤立木からの距離による土のせん断強度 の低滅率の比較や，各立木間の中間点における土のせん断強度の分布などが，京都の都市 林について検討された。これらの研究成果は, 都市周辺に存在する森林の保全機能を高度 に利・活用する場合に有効な，一つの実用的な環境保全林施業法の指針となろう。

\section{Introduction}

The forests in Japan, in response to the various requirements of the national economy, have an important role in providing steady supplies of timber and other forest products.
The forests, on the other hand, possess a function of public benefits as conservation of national land and water resources, filtration of air and water, and promotion of health and recreation for the people. Thus, the forests in Japan have close interaction with the people's

Key words : Urban and suburban forests, Protection forests, Tensile strength of tree root, Shear strength around a solitary tree, Shear strength at the middle of sample between trees.

1) This paper has been summarized at the 19th IUFRO Congress at Montréal in Canada, August 1990.

* Kansai Research Center, For. \& Forest Prod. Res. Inst., Kyoto, Japan. 
life. Especially, as a result of significant economic development of Japan in recent years, the foot of mountains near cities were developed into housing land and leisure facilities in many areas after felling forest trees so that the danger of the occurrence of natural disasters tended to increase. After all, urban and suburban forests around residential areas are more important than remote mountain forests when natural disasters such as landslides, falling rocks, and debris flow are likely to occur. Consequently, it is necessary to improve techniques for the creation and maintenance of urban and suburban forests in order to prevent disasters.

With respect to the effects of forests in urban and suburban areas on the surrounding microclimate, the degree and range of the effects of forests on temperature and humidity has been studied based on the balance of solar energy among forests with different tree species and stand density. On the other hand, the estimation of the environmental conservation effect of urban and suburban forests has not studied completely yet.

In the present research, the slope stability of forests were generally determined from the incidents of slope failures by investigating the forest conditions in mountainous regions where the failures occurred frequently after heavy rains according to the classification such as planted forest, natural forest, conifer tree, broad leaf tree, tree age and forest density.

And it confirms that trees are used to control erosion on slopes, to stabilize landslide scars, and to absorb debris flow impacts. Roots due to their tensile strength and frictional or adhesive properties, reinforce the soil, increase soil shear strength. Particularly, the tree roots may anchor into firm strata providing support with the upslope soil mantle through buttressing and arching.

In this paper, the outline of protection forests in urban and suburban areas was typically proposed, with regard to the existing urban and suburban forests of Japan. And the latest topics about the effect of environmental conservation function of forests from the above mentioned point of view was comparatively discussed. Then we reported on the results of our survey of the actual situation of urban and suburban forests and we discussed the mechanical evaluation method for the beneficial factors in terms of slope stability due to the presence of urban and suburban forests.

\section{Outline of Protection Forest in Urban and Suburban Areas}

The geographical position, topography, soils and climate of Japan constitute favorable environment for growth of forests in general. On the other hand, Japan is susceptible to various disasters. The annual calamities in Japan caused by heavy rains, typhoons and earthquakes amount to $\$ 90$ million on the average. The frequency of damages caused by physical factors is quite high in the world. Such calamities are often caused by landslides after rainfall, or soil loss from mountainous lands. In an expectation of effective prevention of flood damage, and conservation of soil and water, based on the principle of "one who controls the soil and water, controls the forest", efforts have been devoted to formation of well managed forests.

The protection forest system in Japan has its real genesis in the function of forests of public utility, i.e., conservation of headwaters as shown in Photo. 1, prevention of washout and other damages caused by wind, snow and tide, promotion of recreational and scenic values and protection of industry as well as in establishing "protection forests" in the areas where such functions are needed. This system has been established based on the Japanese Forest Law promulgated in 1897 and several modifications have been made since then.

The protection forests are divided into 17 types according to their purpose, and their types and area as of 1988 are shown in Table 1. The area of 1988 has increased by approximately three 
Table 1 Area of protection forests in Japan, in 1988. (Unit : 100 ha)

\begin{tabular}{|c|c|c|c|c|c|}
\hline No. & Types & National & Private & Total & Ratio(\%) \\
\hline 1 & Headwater Conservation Forest & 3,104 & 2,810 & 5,914 & 73 \\
\hline 2 & Erosion Control Forest & 708 & 1,070 & 1,778 & 22 \\
\hline 3 & Soil Conservation Forest & 13 & 32 & 45 & 1 \\
\hline 4 & Shifting Sand Control Forest & 4 & 12 & 16 & 0 \\
\hline 5 & Windbreak Forest & 23 & 31 & 54 & 1 \\
\hline 6 & Flood Control Forest & 0 & 1 & 1 & 0 \\
\hline 7 & Tidebreak Forest & 5 & 7 & 12 & 0 \\
\hline 8 & Drought Prevention Forest & 15 & 21 & 36 & 0 \\
\hline 9 & Snowbreak Forest & 0 & 0 & 0 & 0 \\
\hline 10 & Mistbreak Forest & 9 & 43 & 52 & 1 \\
\hline 11 & Avalanche-break Forest & 3 & 14 & 17 & 0 \\
\hline 12 & Falling-stone-break Forest & 1 & 1 & 2 & 0 \\
\hline 13 & Firebreak Forest & 0 & 0 & 0 & 0 \\
\hline 14 & Fish Trap Forest & 6 & 20 & 26 & 0 \\
\hline 15 & Navigation Target Forest & 0 & 0 & 0 & 0 \\
\hline 16 & Recreation Forest & 57 & 48 & 105 & 1 \\
\hline 17 & Aethetic Forest & 7 & 9 & 16 & 0 \\
\hline \multicolumn{2}{|c|}{ Total } & 3,955 & 4,119 & 8,074 & 100 \\
\hline \multicolumn{2}{|c|}{ Ratio to total protection forest (\%) } & 49 & 51 & 100 & \\
\hline \multicolumn{2}{|c|}{ Ratio to total forest area $(\%)$} & 16 & 16 & 32 & \\
\hline
\end{tabular}

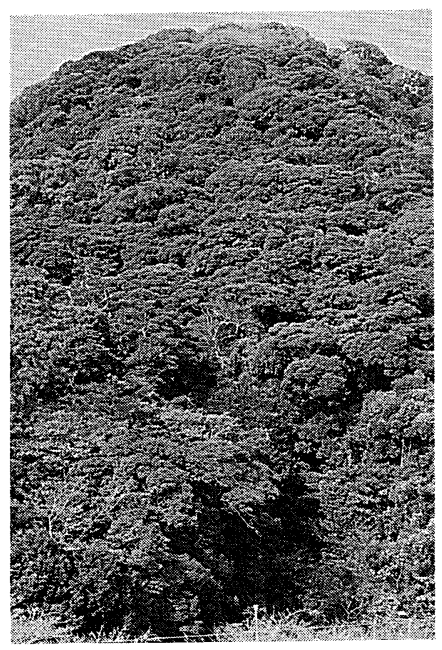

Photo. 1 Typical headwater conservation forest in Japan. (Suburban forest near Hagi city)

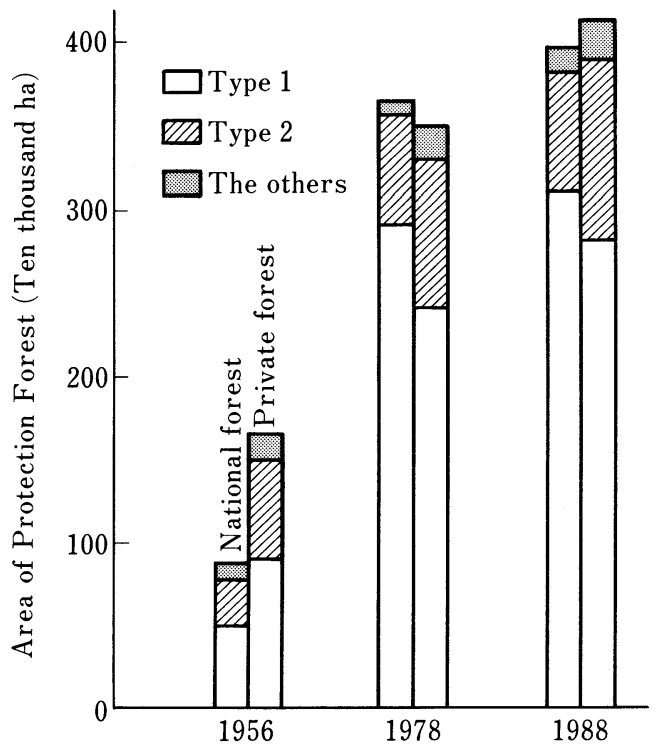

Fig. 1 Areal change of protection forests by ownership. 
times that of 1956 as shown in Fig. 1, (Suyama, 1989).

Three restrictions are imposed on the management of protection forests : restriction of felling of standing trees, conversion of topography and obligation of planting. Felling of standing trees is to be done within the framework of the management plan which provides felling system (clear cutting, selective cutting and cutting prohibition) and the annual cutting area and the conversion of the land type is regulated as to require the permission of the governor concerned. After felling, the regulation provides to plant within 2 years.

Owners of protection forests consist of the State, local public entities, firms, and individuals. Since private property is restricted for use for public service, the government grants the following special favours.

1) Tax exemption and reduction

2) Financing

3) Raising of reforestation subsidy

4) Execution of planting at the expense of the government in case of natural disasters

5) Availability of profit sharing reforestation with the public entity

6) Monetary compensation for loss

\section{Experimental Results and Discussions}

\section{Tensile Strength of Tree Roots}

The tensile test of tree roots was made, according to the testing method using the modified tapering root specimen which has already proposed (Suyama, 1988).

The biaxial tensile load was applied through and along the center of specimen by universal Instron type testing machine (Shimazu REH 30) as shown in Photo. 2. Load histories against specimen displacement were recorded autographically.

The specimens were loaded on the second day after they were dug out of the ground. The rate of loading for all specimens was approximately $60 \mathrm{~kg} / \mathrm{min}$., until fracture initiated.

For the tensile test in this study, we selected

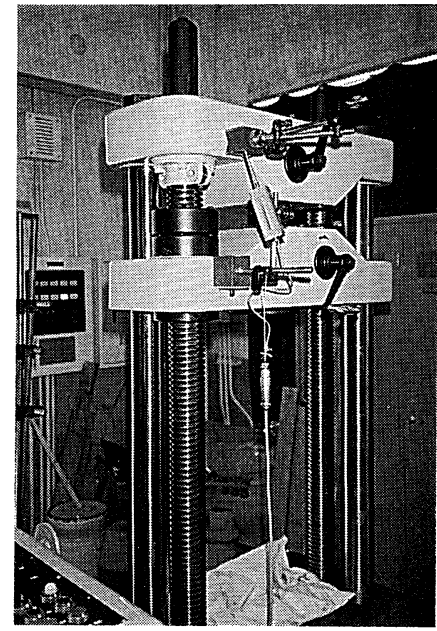

Photo. 2 Biaxial tensile testing machine of tree roots. (Shimazu REH-30)

the species of Japanese black pine (Pinus thunbergii Parl.) as vertical root type, Japanese zelkova (Zelkova serrata Makino) and Toringo crabapple (Malus sieboldii Rehd.) as lateral root type, Indigobush (Amorpha fruticosa L.), Beech (Fagus crenata Blume), and Japanese cherry (Prunus donarium Sieb.) as radiant root type, respectively. These species grow side by side at flat area, in the same silty clay loam soil of Chiyoda Experimental Site, Forestry and Forest Products Research Institute, in Japan. The species of Japanese cherry is four years old and the others are all six years old.

Fig. 2 shows the exponential regression curves of extension ratio $(d)$ on diameter $(D)$ of root specimen for the tree species of Japanese zelkova, Toringo crabapple, Beech, and Indigobush. The exponential regression equation can be expressed as :

$$
d=a \cdot D^{b}
$$

where $a$ and $b$ are constants to be evaluated, $d$ is extension ratio, and $D$ is root diameter (inside bark) at the midsection of tapering portion.

The tensile strength (Maximum load, $P$ ) of roots was plotted against the diameter $D$, for the tree species of Japanese zelkova, Toringo 


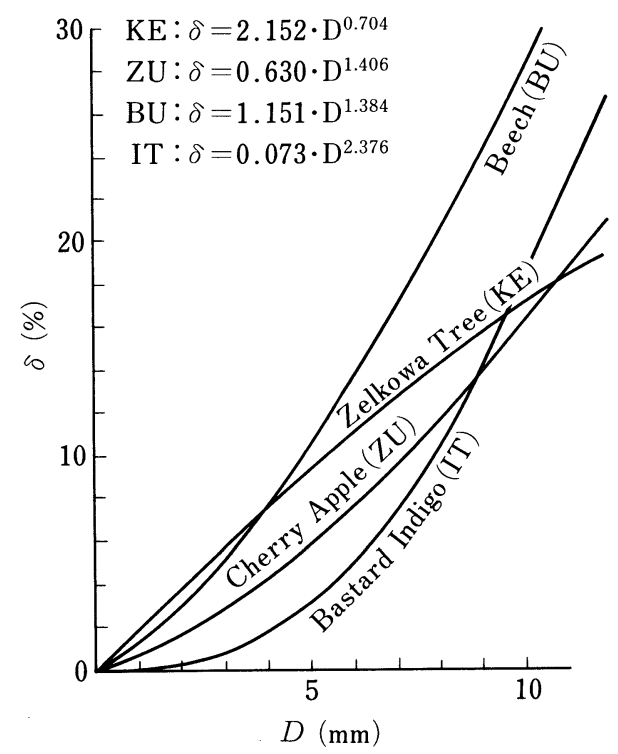

Fig. 2 Exponential regression curves of extension ratio $(d)$ on diameter $(D)$ of root specimen.

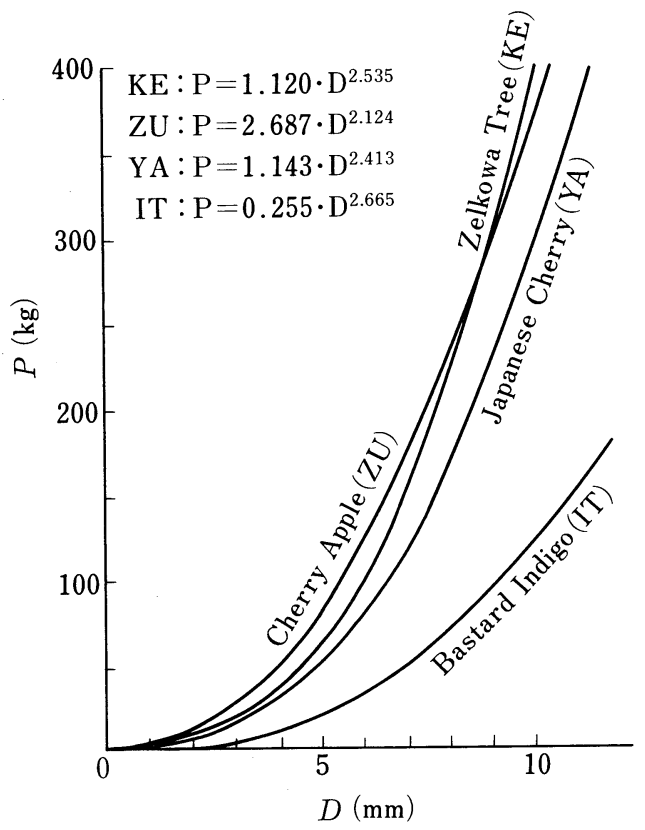

Fig. 3 Exponential regression curves of maximum load $(P)$ on diameter $(D)$ of root specimen. crabapple, Japanese cherry, and Indigobush, shown in Fig. 3, and these results showed distinct differences of tensile strength for the four species. The exponential regression equation can be also expressed as :

$$
P=\alpha \cdot D^{\beta}
$$

where $\alpha$ and $\beta$ are constants to be evaluated, $P$ is maximum load, and $D$ is the root diameter ditto.

The tensile strength of individual roots has seldom been examined. Only few examples are shown that O'Loughlin's plotted data (1974) for live Coast Douglas fir roots, with the predicted curve from Burroughs's study (1977) superimposed. This predicted curve is useful in estimating the root strength, but the limit of application must be narrow, due to the difference of specimen size and tree species.

From the author's experimental data (SUYAMA, 1985) of individual root tensile test, we found that the regression equation was nonlinear for each species with a function of root diameter. In this study, we investigated the problem from the viewpoint of strength of materials, whether the effects of the tree species upon the tensile strength can be explained or not.

Fig. 3 shows the test results for the specimens with geometrical similarity of different species. In this figure, the tensile strength curve calculated by using the modified specimen for each tree species is illustrated, and it can be seen that the calculated curve agrees well with the experimental results.

Thus, it is concluded that the individual root tensile strength for the various size and species can be predicted by using the new modified root specimen.

\section{Shear Strength of Soil Horizon}

In order to predict the limitation of shear strength of soil horizon within the sphere of roots in urban and suburban forests, the vane shearing test in situ (Photo. 3) was carried out at the center of spacing between trees in comparatively dense plantation, as shown in Fig. 4. The plantations of Japanese black pine (Pinus 


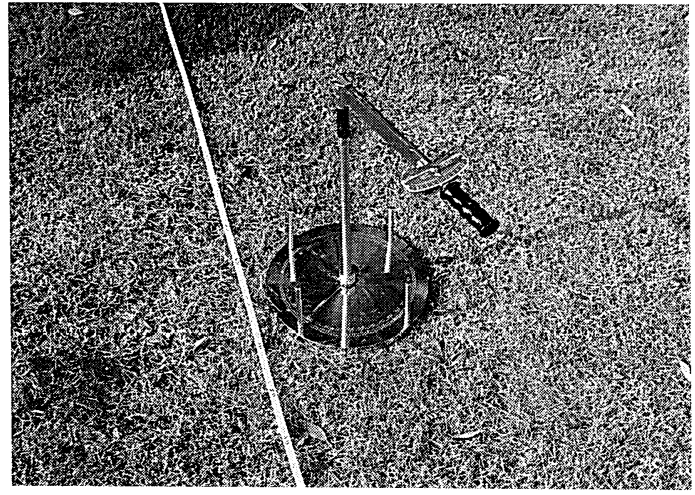

Photo. 3 Portable vane shear testing tool in situ.

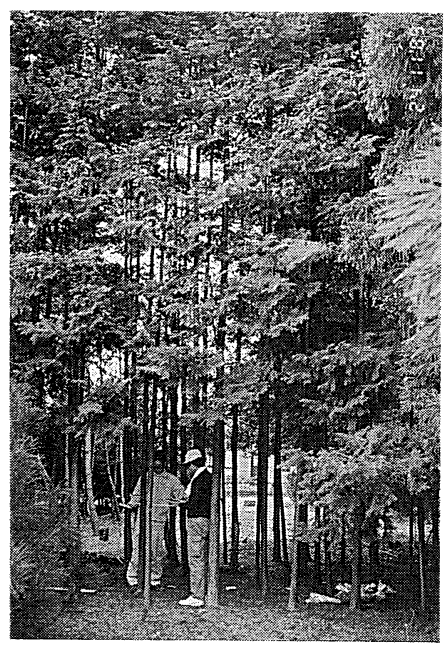

Photo. 4 Vane shear testing of soil horizon in dense plantation of Japanese cypress. (Southern part of Kyoto city)

thunbergii) and Japanese cypress (Chamaecyparis obtusa), as shown in Photo. 4, were chosen for the test stands (Table 2) in a suburban forest in Kyoto. The former stand was nine years old, and the latter was twelve years old.

A summary of the experimental results is shown in Table 2. The measured shear strength values for two different stands were about the

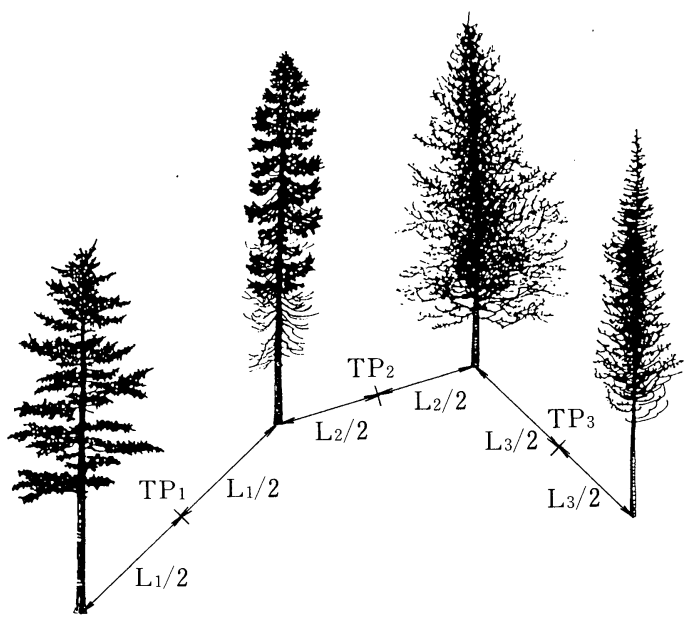

Fig. 4 Shearing test position at the middle of the trees.

Note TP: Shearing test position, $\mathrm{L}$ : Distance between trees.

Table 2 Comparison of shear strength in dense plantation

\begin{tabular}{lcc}
\hline Tree species & $\begin{array}{c}\text { Japanese } \\
\text { black pine }\end{array}$ & $\begin{array}{c}\text { Japanese } \\
\text { cypress }\end{array}$ \\
\hline Age (years) & 9 & 12 \\
Mean height(m) & 4.8 & 7.5 \\
$\begin{array}{l}\text { Mean spacing } \\
\text { between trees (cm) }\end{array}$ & 88.0 & 84.5 \\
$\begin{array}{l}\text { Stand density } \\
\text { (trees/ha) }\end{array}$ & 13,000 & 14,000 \\
$\begin{array}{l}\text { Shear strength } \\
\left.\text { (kg/cm }{ }^{2}\right)\end{array}$ & $0.764-0.611$ & $0.873-0.742$ \\
$\begin{array}{l}\text { Soil hardness(mm) } \\
\text { Diameter groud }\end{array}$ & $21-24$ & $18-23$ \\
level(cm) & $4.8-9.9$ & $4.8-16.2$ \\
\hline
\end{tabular}

same, and the shear strength was $611\left(\mathrm{~g} / \mathrm{cm}^{2}\right)$. The soil hardness of forest floor was comparatively high because the both stands had the crown of high density.

On the other hand, in order to obtain the limitation of fiber reinforced action which affects the shear strength increase, the vane shearing test was made in the soil horizon within the sphere of roots around a solitary test trees, in a sparsely planted Loblolly pine (Pinus 
taeda) forest and four species of garden forests.

The Loblolly pine stand was 28 years old and the mean height was 16 metres. The test tree was isolated at intervals of three metres and over from its adjacent tree, the diameter brest height was $30.1 \mathrm{~cm}$, and the diameter ground level was $37.6 \mathrm{~cm}$, respectively. The shear strength, soil hardness, and root content ratio were measured at experimental points established $0.5,1.0,2.0,3.0$ meters distant from the solitary test tree in radial direction around the tree. The experimental results are indicated in Fig. 5 .

The result of the shearing test indicates that the closer a radial distance gets to the solitary test tree, the larger a shear strength of soil horizon becomes. The shear strength took the value of $700\left(\mathrm{~g} / \mathrm{cm}^{2}\right)$ and over at the circumference of a solitary tree, but the strength decreased by 35 percent at the distance of three metres from the stumpage. The root content ratio became maximum at the distance of one metre from the stumpage.

With respect to the other tree species investigated in the garden forest, the vane shearing test

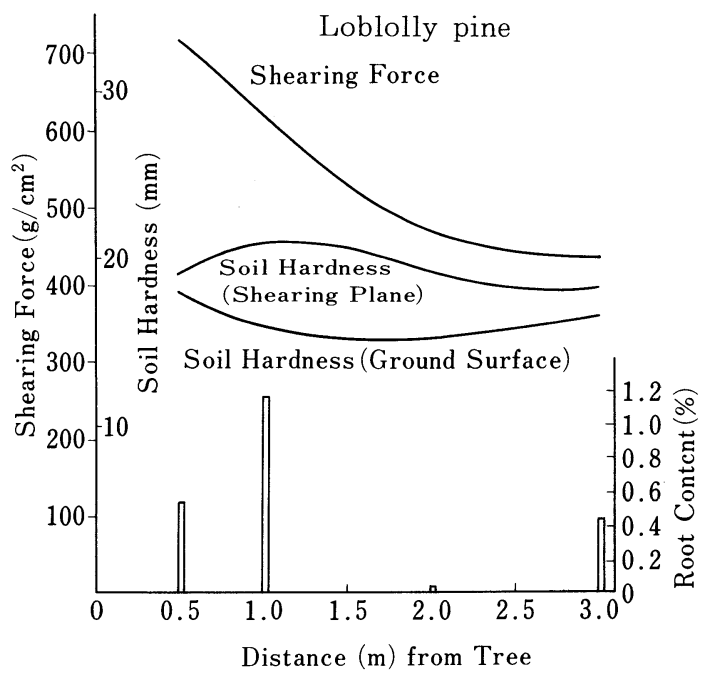

Fig. 5 Distribution of shear strength of soil horizon and soil hardness around a solitary Loblolly pine tree. in situ was also carried out around the trees such as Japanese black pine (Pinus thunbergii) as coniferous forest, Pasania tree (Castanopsis cuspidata) as laurel forest, Oak tree (Quercus glauca) as laurel forest, and Japanese zelkova

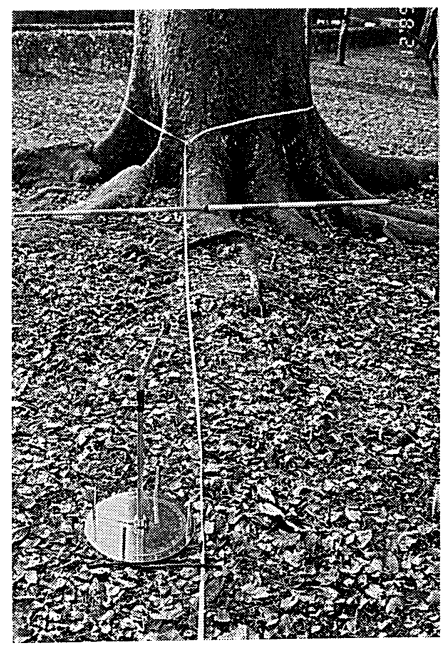

Photo. 5 Vane shear testing of soil horizon within the sphere of roots around a solitary tree of Japanese zelkova. (Northern part of Kyoto city)

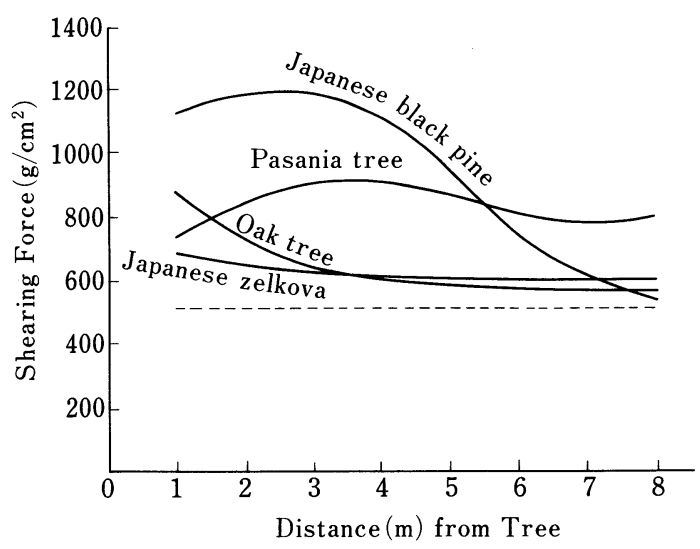

Fig. 6 Comparison of shear strength decreases due to distance from a solitary test tree. 
(Zelkova serrata) as leaf-fall broad leaved forest, as shown in Photo. 5. These trees were all rather big. The shear strength of soil horizon within the sphere of roots at each point of radial director from ground level of stumpage was measured.

A summary of the experimental results is shown in Fig. 6. As a result, it is apparent that the shear strength decrease due to distance from a solitary tree is quite different among the tree species.

In this paper, we have picked up several points concerning increase in shear strength due to tree roots. There still remains some theoretical problems, but this experimental result gives many hints to the problem of management of urban and suburban forests.

\section{Literature Cited}

1) Burroughs, E.R. and Thomas, B.R., 1977 : Declining root strength in Douglasfir after felling as a factor in slope stability. U.S. Dep. Agric. For. Serv. Res. Paper INT 190., Ogden, UT, USA

2) O'Loughlin, C.L., 1974 : The effect of timber removal on the stability of forest soils. Jour. Hydrol. (N.Z), vol. 13 , no. 2, pp. 121-134

3) O'Loughlin, C.L., 1974 : A study of tree root strength deterioration following clearfelling. Can. J. For. Res., no. 4 , pp. 107-113

4) Suyama, M. and Hara, T., 1985 : Biotechnical slope stability by root systems (I)-Tensile strength testing of tree roots for slope stability-. Trans. 96th. Anual Meeting of the Japan Forest Society, pp. 643-644

5) Suyama, M., 1988 : Experimental study on biotechnical slope stability by plant root systems. Mitteilungen der Forstlichen Bundesversuchsanstalt (Wien), MITTEILUNGSBAND NR. 159/1988, pp. 117-126

6) Suyama, M., 1989: The estimation of environmental conservation effect for the existing urban forest. Water Science, vol. 33, no. 1, pp. 1-33 